$\mathrm{WP} / 06 / 65$

Revised: 6/26/06

\title{
Volatility of Development Aid: From the Frying Pan into the Fire?
}

Alě̌ Bulír and A. Javier Hamann 



\title{
IMF Working Paper
}

IMF Institute

Volatility of Development Aid: From the Frying Pan into the Fire?

Prepared by Aleš Bulíř and A. Javier Hamann ${ }^{1}$

Authorized for distribution by Enrica Detragiache

March 2006

\begin{abstract}
This Working Paper should not be reported as representing the views of the IMF. The views expressed in this Working Paper are those of the author(s) and do not necessarily represent those of the IMF or IMF policy. Working Papers describe research in progress by the author(s) and are published to elicit comments and to further debate.

The positive impact of foreign aid is limited by the erratic behavior of aid flows. The introduction in 1999 of various initiatives anchored in Poverty Reduction Strategy Papers (PRSPs) which were aimed at strengthening coordination among donors, improving the design of financial support programs, and improving domestic records of policy implementation should have led to an improvement in the time series properties of aid flows. We find no evidence of any fundamental changes in the way aid has been delivered in the past five years. If anything, aid volatility has worsened somewhat and the information value of long-term lending commitments has declined. We take these results to mean that the main causes of the volatility and unpredictability of aid, and the broader issue of macroeconomic instability in low-income countries, have not been addressed in a systematic manner by the donor community.
\end{abstract}

JEL Classification Numbers: F35, 019

Keywords: External aid, ODA, volatility, predictability

Author(s) E-Mail Address: abulir@imf.org, ahamann@imf.org

${ }^{1}$ A. Buliŕ is with the IMF Institute and A. J. Hamann is with the Independent Evaluation Office of the IMF. We are grateful to Christopher Adam, Andy Berg, Oya Celasun, Tom Crowards, Tina Daseking, David Goldsbrough, Tim Lane, Alex Mourmouras, Mark Plant, Russell Kincaid, and various other colleagues at Department for International Development (DFID) and the IMF. We would also like to thank the participants of the "Seminar on Foreign Aid and Macroeconomic Management" (Maputo, March 14-15, 2005) and several IMF seminars for constructive comments and suggestions. 


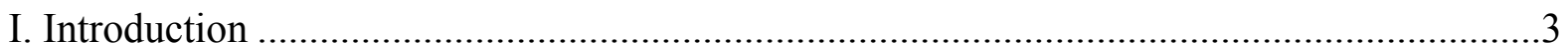

II. Volatility and Predictability of Aid: What Exactly Is the Issue? ...................................4

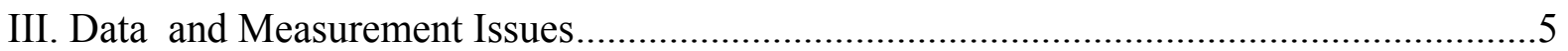

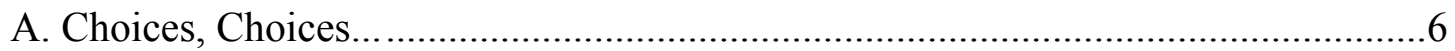

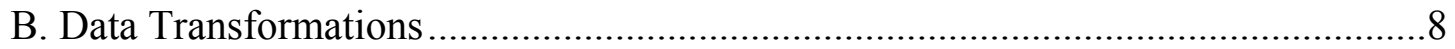

IV. Measuring the Variability of Aid: Three Approaches ............................................. 9

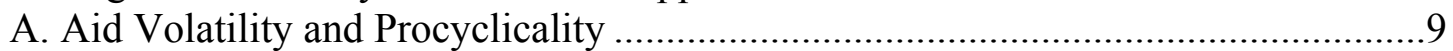

B. Predictability ............................................................................................. 16

C. Aid and Macroeconomic Shocks: Beyond Procyclicality of Aid ..........................18

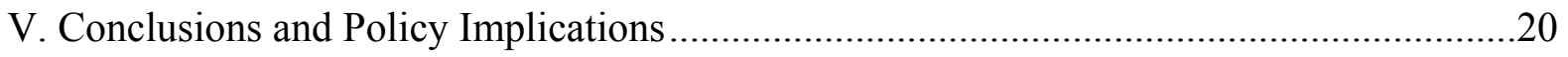

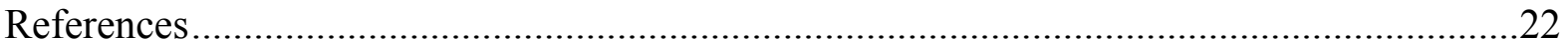

Appendices

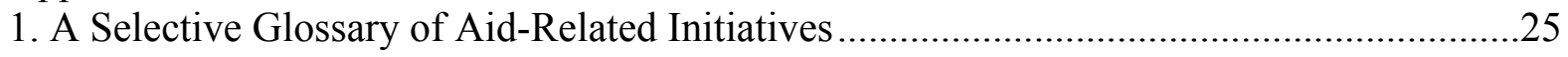

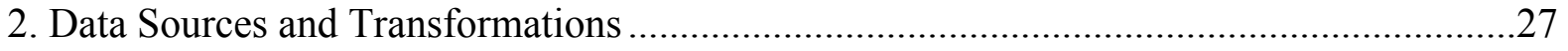

Tables

1. Aid Is More Volatile than Revenue and Procyclical, 1975-2003 ....................................10

2. During 2000-03 Aid Has Been More Volatile than Ever Before........................................12

3. The Patterns of Aid Volatility in HIPC and Non-HIPC Countries Remain Broadly Unchanged, 1995-2003 ...................................................................... 13

4. Aid Has Been Poor Insurance against Negative GDP Shocks, 1975-2003 .......................19

Figures

1. Aid Is Important, Albeit Declining, Resources for Aid Recipients, 1975-2003 _................7

2. Countries Receive Unstable Aid Flows, 1975-2003 ..................................................

3. Selected Countries: Relative Volatility of Aid and Revenue, $\Phi, 1975-2003$....................14

4. Aid Is Getting More Volatile; Revenue Remains Stable, 1975-2003 ..............................15

5. Commitments Are Poor Predictors of Disbursements, 1975-2003 ..................................17

Appendix Tables

A1. List of Countries and Sample Periods .....................................................................29

A2. Aid Is Volatile: Nevermind the Definitions and Smoothing Techniques ........................30 


\section{INTRODUCTION}

The volatility and unpredictability of aid as a problem of macroeconomic management in low-income countries are receiving increasing attention in academia, as well as among bilateral donors and international financial institutions (IFIs). Nancy Birdsall (2004) has recently highlighted the problem in her typology of donor sins-her number 6 is called "stingy and unreliable transfers." A study by the OECD (2003) identified "uncoordinated donor practices" and "delays in disbursements" as two of the five most burdensome donor practices. In February 2005 Group of Eight (G-8) finance ministers recommended that donors "deliver aid in a more predictable way" (H.M. Treasury, 2005).

These coordination problems of development assistance were identified long time ago - see, for example, Griffin and Enos (1970), Tendler (1975), or Cassen and Associates (1986). Donors fail to communicate with each other, move in herds, pumping money into "trendy" sectors or "star" countries, while neglecting others. Brief periods of substantial increases in the volume of aid, measured by Oversees Development Assistance $(O D A)$, tend to be followed by secular declines. As a result, donor-specific conditionality is either overlapping or contradictory, and reforms have been typically forced upon low-income countries. Between the influential Cassen report and the late 1990s, a few major initiatives strived to improve the allocation of aid and incorporate aid better in the context of macroeconomic policies in low-income countries. The major initiatives were the Enhanced Structural Adjustment Facility of 1987, Heavily Indebted Poor Countries (HIPC) Initiative of 1996, and Poverty Reduction Strategy Paper (PRSP) of 1999 (see Appendix I for some institutional details). Each of these initiatives aimed at addressing the above shortcomings of development assistance once and for all.

Yet, many in the donor community are more frustrated than ever before by a noticeable lack of coherence in the treatment of low-income country problems - a point recently stressed by Lockhart (2005). Specifically, the implicit goal of consumption smoothing, which could lead to sizable welfare gains in low-income countries, is not well integrated into the analysis. This will require greater recognition by donors and IFIs of the magnitude of the cost of macroeconomic instability and also of their commitment to make reduced volatility an explicit goal for development assistance. The challenge for IFIs is to improve program design, particularly in the area of contingency planning. For bilateral donors, the challenge implies preventing aid from becoming a source of macroeconomic volatility and allowing a portion of aid to be used explicitly to neutralize other sources of volatility. For their part, aidrecipient countries need to commit to less erratic policy implementation, which could go a long way toward more stable aid disbursements.

This paper updates our previous work on aggregate aid volatility and predictability (Bulír and Hamann, 2003). We have tried to incorporate several suggestions made to us since the publication of that paper, mainly those related to verifying the robustness of our results. Many other useful suggestions, such as breaking down the analysis by type of donor or type of aid, have been left out, as we believe that they fall beyond the scope of this paper.

In the remainder of this paper, we outline the problem, describe the data, and analyze in turn three alternative measures of aid instability: relative volatility vis-à-vis fiscal revenue, 
unpredictability of aid disbursement relative to commitments, and failure of aid to smooth fluctuations in aggregate income. We then draw some policy implications.

\section{Volatility and Predictability OF Aid: What Exactly Is The Issue?}

The issue of aid volatility did not feature prominently in the literature until fairly recently. Before the 1990s, the debate was centered on the effectiveness of the volume of aid and economists typically looked at aid committed and disbursed over long periods of time. ${ }^{2}$ Subsequent research showed that aid was highly volatile, far exceeding that of other macroeconomic variables, such as GDP or fiscal revenue (Pallage and Robe, 2001; Bulír and Hamann, 2003; Fielding and Mavrotas, 2005). Other key findings include the mild procyclicality of aid disbursements (i.e., aid tends to be disbursed mostly in periods when output or domestic revenue is high and held back when domestic economic activity is contracting) and the fact that aid disbursements are difficult to predict, particularly on the basis of donor commitments (Bulír and Hamann, 2003).

Aid-dependent countries are typically prone to large external shocks and are less able to cope with them, owing to their pervasive liquidity constraints and the lack of effective countercyclical policy tools. In this context, volatile, unpredictable, and procylical aid can heighten overall macroeconomic instability, thus detracting from other beneficial effects of aid. Empirical estimates show that the consequences of aid volatility for aggregate growth and consumption are sizable (Lensink and Morrisey, 2000; Pallage and Robe, 2003; Arellano and others, 2005; Torsvik, 2005). Not surprisingly, some of these models also illustrate the substantial potential gains, in terms of the stability of aggregate consumption, of disbursing aid in a stable and predictable manner.

Experience shows that the adverse characteristics of aid disbursements highlighted above are not easy to correct for various reasons. First, aid volatility reflects deeply rooted problems with the way donor budgets are approved and administered. ${ }^{3}$ Among other things, donor development agencies that make aid commitments are different from those that approve aid funding (parliaments) and disburse aid (ministries of finance). While the magnitude of this disconnect differs from country to country, it seems to be widespread.

A second source of aid volatility is conditionality - not only the conditions attached by bilateral donors, but frequently the requirement that aid recipients have the "seal of approval" associated with an on-track IMF-supported adjustment program. There are two sides to this issue. From the country's point of view, it means that complying with conditionality is

\footnotetext{
${ }^{2}$ The neglect of volatility was not unique to development economics as the link between volatility and growth has been demonstrated only recently by Ramey and Ramey (1995). For a recent empirical study on the link between volatility and growth, see Cerra and Saxena (2005).

${ }^{3}$ The following citation exemplifies the vagaries of donor aid budgets: the U.S. administration announced that it would ask Congress for $\$ 1.7$ billion in 2004 but it asked for $\$ 1.3$ billion. In the end, only $\$ 1$ billion was approved by Congress (New York Times, 2005).
} 
important not only because of the merits of the policies to which conditions are attached but also because it reduces volatility in aid inflows (Bulír and Lane, 2004). From the donors' perspective, there is a tension between the need to ensure that "good policies" are being implemented - donors are accountable to domestic constituencies for the aid funds they disburse - and the negative impact of disruptions in aid disbursements. Thus, conditional aid entails a tradeoff between the pursuit of good policies aimed at securing sustainable growth and poverty reduction, and the objective of providing a smooth stream of aid that could go a long way towards achieving the goal of consumption smoothing in low-income countries.

Against this background and under the umbrella of the PRSPs, since the late 1990s, the donor community and the IFIs have together developed a number of initiatives that could be rationalized as attempts at improving the terms of the tradeoff described above by:

- improving domestic policymaking processes in aid-recipient countries,

- designing lending facilities better tailored to country-specific realities and based on improved modalities of conditionality,

- $\quad$ providing debt relief, and

- harmonizing donor conditionality.

In this paper, we follow the methodology employed by Bulír and Hamann (2003), with some minor modifications, and extend the series from 1975-1997 to 1975-2003. This longer period includes some years since the introduction of the PRSP and allows us to assess whether the PRSP-related initiatives have led to a marked change in the behavior of aid flows.

The results are not encouraging. We continue to find that the volatility of aid is a multiple of that of domestic fiscal revenue. Furthermore, we find little evidence that the relative volatility of aid has decreased recently. Aid commitments are still inadequate predictors of disbursements, particularly for the poorest countries in our sample. As far as macroeconomic shocks are concerned, aid is failing to compensate for negative GDP shocks. For example, countries hit by negative GDP shocks equivalent to 5 percent or more received a meaningful increase in aid in only one out of seven cases.

We do not test directly how the various initiatives introduced in the late 1990s and aimed at improving donor practices, domestic policy processes, program design, and so on have fared. But we find no prima facie evidence that they have had any meaningful impact on how aid is delivered. We take this to mean that the main underlying causes of aid volatility and unpredictability have not been confronted or addressed in a systematic manner. Unless this is done, we see little reason to be optimistic about the contribution of the recently created initiatives and lending facilities (Appendix I).

\section{DATA AND MeAsurement IsSUES}

Compared with Bulír and Hamann (2003), we extended the sample, added a few countries, filled some gaps in the coverage of domestic fiscal revenue (see Appendix II for a detailed description of all series and their transformations), and tested robustness of our results using 
alternative aid definitions and smoothing techniques. Our database contains 76 countries from 1975 to 2003, with both gross and net aid series and domestic revenue series (both tax and nontax). Given that not all the revenue series are available from 1975, we have an unbalanced panel of observations (see Table A1 for data availability). Figure 1 shows the evolution of gross aid, excluding food and emergency aid and debt relief, in our sample countries, and Figure 2 shows aid profiles of individual countries. ${ }^{4}$

\section{A. Choices, Choices...}

The specific definition of aid seems to matter surprisingly little-our results in sections IV.A and IV.C remain robust for every definition of aid we employed. One choice is between gross aid (disbursements) and net aid (disbursements net of repayments). However, net aid measures may be misleading if the recipient country is in arrears or in the process of rescheduling, as accrual-based debt service does not necessarily reflect actual repayments. Another choice is between a narrow definition (grants and loans, excluding food and emergency aid and debt relief) and broader definitions that include these inflows. The main disadvantage of broader definitions is that the contemporaneous macroeconomic impact of broadly defined aid is more difficult to anticipate. For example, emergency aid is often fully under control of donors, debt relief may have no impact on the contemporaneous cash flow of the recipient country, and so on. Thus, for the reasons above, we focus on narrow definitions of gross aid. Our results remain broadly unchanged when net aid or broadly defined gross aid is used.

The choice of a common denominator matters more for the statistical measures of relative volatility than the definition of aid. Typically, aid is denominated in U.S. dollars whereas domestic revenue is denominated in local currency units. Comparisons require first expressing both variables in the same currency. As a result, statistical measures of relative volatility are affected by the volatility of exchange rate, whose impact can be very large. To control for the impact of exchange rate volatility, we compute aid and revenue in three different ways: as percentages of nominal GDP, in constant U.S. dollars in per capita terms, and as percentages of purchasing-power-parity (PPP) GDP. Arguably, denominating aid and revenue in per capita U.S. dollars is preferable if they both were to be spent on tradable goods, whose prices tend to be fixed in U.S. dollars (Bulír and Lane, 2004). In reality, a significant portion of aid proceeds is spent on nontradable goods. More generally, if the objective is to assess the macroeconomic impact of aid, the relevant denominator is the aidto-GDP ratio. Furthermore, using PPP-based series should, in principle, reduce the noise introduced by the volatility of the exchange rate. Henceforth, owing to the lack of an ideal denominator, we use all three transformations as a robustness check.

\footnotetext{
${ }^{4}$ For a broader picture of recent aid developments see Gupta et al. (2006).
} 
Figure 1. Aid Is an Important, Albeit Declining, Resource for Aid Recipients, 1975-2003 (Full sample annual averages, $\mathrm{N}=76$ )
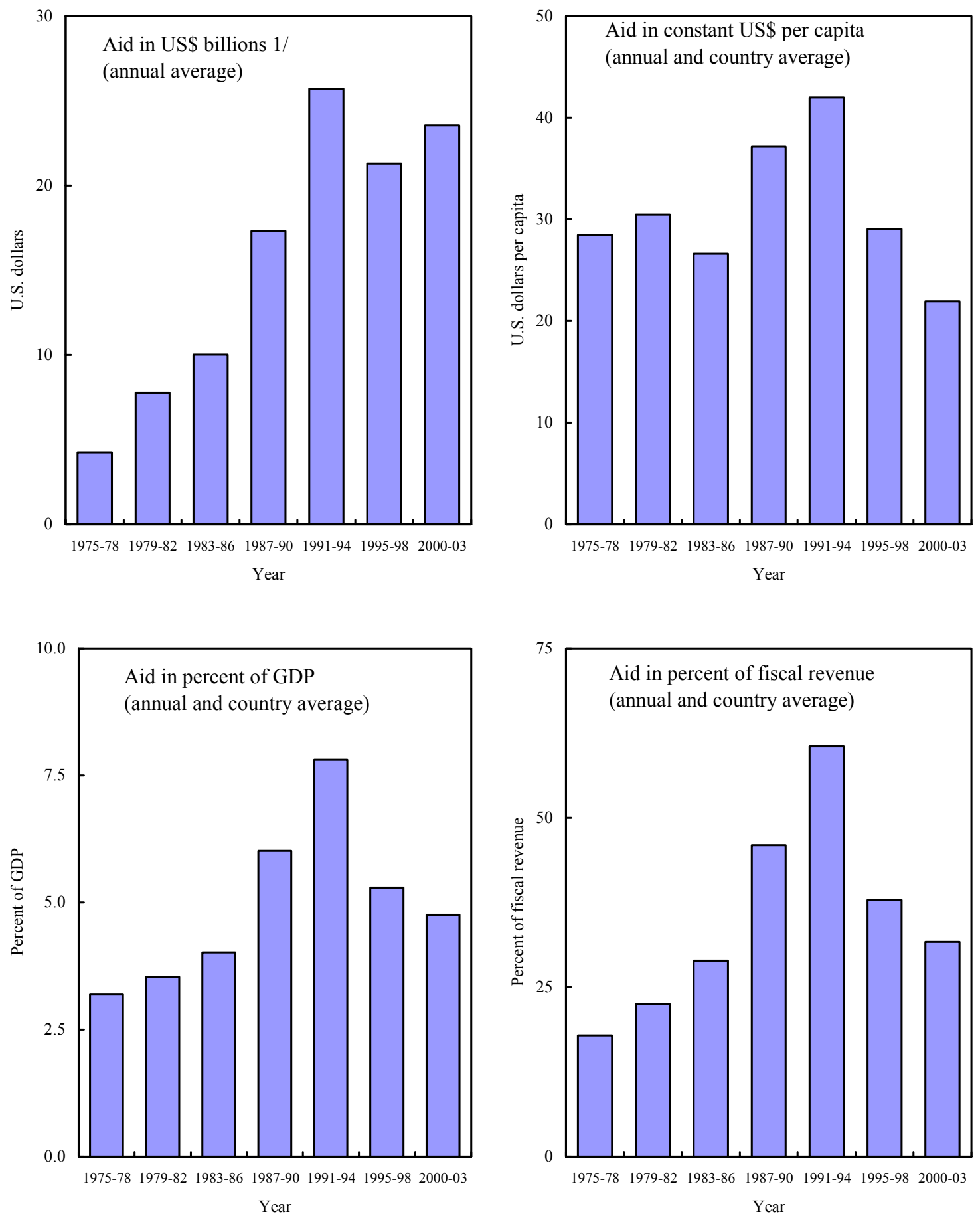

Source: OECD; International Financial Statistics; World Economic Outlook; authors' calculations.

1/ Aid includes ODA grants and disbursed ODA loans, excluding food and emergency aid, and debt relief. 
Figure 2. Countries Receive Unstable Aid Flows, 1975-2003

(In percent of GDP)

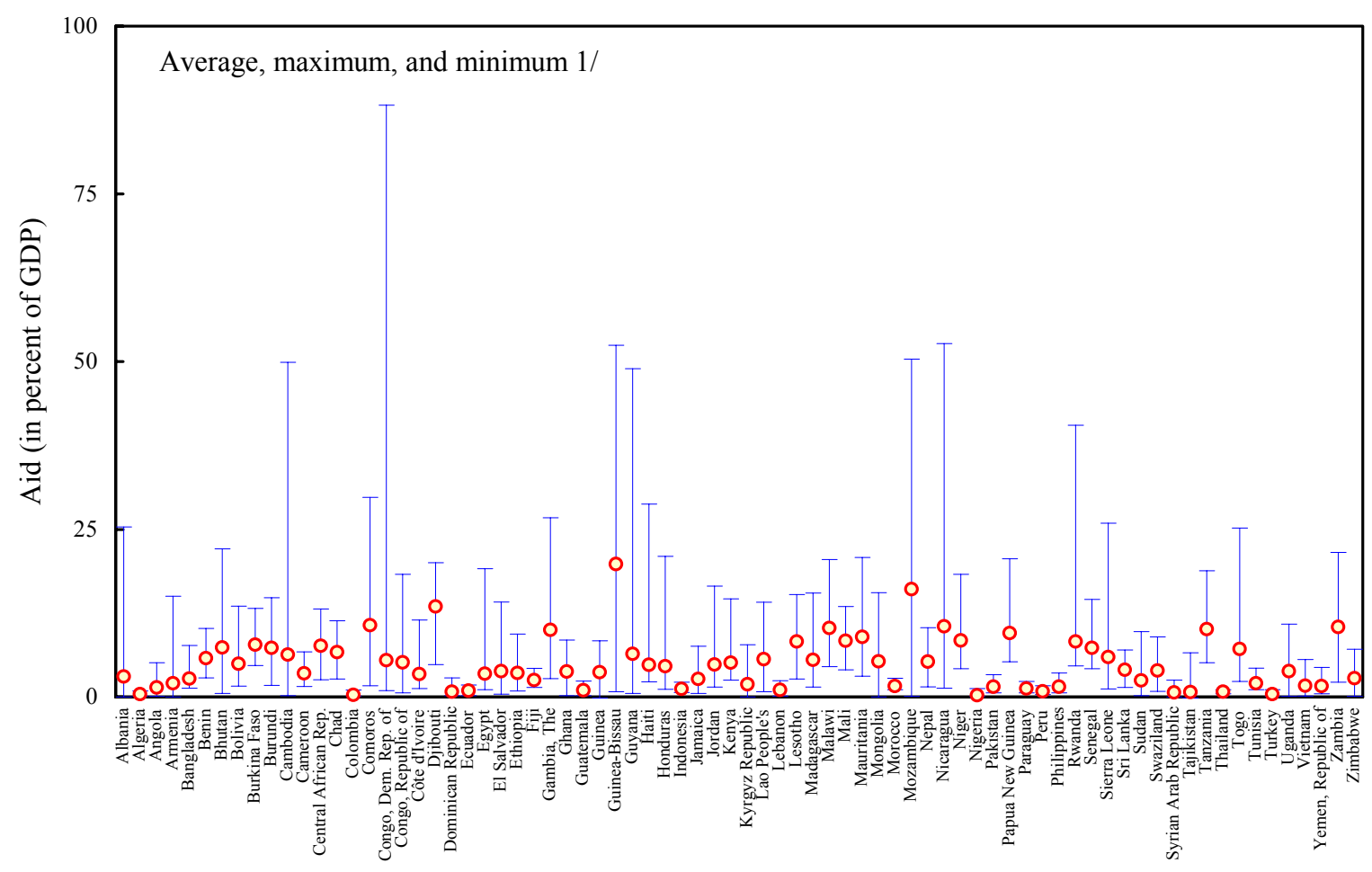

Source: $O E C D$ and $W E O$; authors' calculations.

1/ Circles indicate sample averages of individual countries (mean of 4.9 percent) and the upper and lower bars indicate sample maxima and minima (whose averages are 10.5 percent and 3.6 percent, respectively). $\mathrm{N}=76$.

\section{B. Data Transformations}

All transformed aid and revenue series are converted into natural logarithms and de-trended using the Hodrick-Prescott filter. A measure of relative aid volatility is then calculated, $\Phi$, as the ratio of the variances of the filtered series of aid and revenue. ${ }^{5} \Phi$ is a ratio of variances, estimated with a common number of observations per country in both the numerator and denominator, and the statistical significance of sample averages can be done using an $F$-test. Additional robustness checks are comparisons of sample averages and medians of $\Phi$ across countries and various groups of countries. Finally, we calculate the correlation coefficient of de-trended aid and revenue, which amounts to a test of aid procyclicality as revenues are a strongly procyclical variable.

\footnotetext{
${ }^{5}$ The logs eliminate the scale problem present in the series, which would otherwise bias the estimates of $\Phi$ downward. For example, given that the absolute level of aid is around one-third of the level of revenue in current exchange rates (Table 1), all else equal, the variances of domestic revenue could then be up to ten times larger than those of aid.
} 


\section{Measuring the VARiability OF Aid: Three APPROAChes}

In this section we reexamine the evidence on volatility and predictability of aid since our previous study. As stated earlier, the year 1999 provides a natural breaking point for the analysis as it marks the introduction of the PRSP initiative, which was expected to be the cornerstone of many initiatives introduced simultaneously (or shortly thereafter) and aimed at addressing key issues such as insufficient donor coordination or a lack of ownership by aid recipient countries (Appendix I). Thus, by contrasting the pre-1999 and post-1999 periods, we try to answer three questions:

- Does aid continue to be, for the most part, more volatile than domestic revenue?

- Has aid become more predictable (i.e., are aid disbursements more closely related to donor commitments)?

- Are aid inflows related to macroeconomic shocks in the recipient countries?

Despite building on a larger sample and a statistical methodology that focuses on pure volatility of aid and revenue, our findings are very much comparable to those of Bulír and Hamann (2003). We find no positive impact of the policy initiatives described earlier on the relative volatility of aid. More specifically, we find that aid:

- has been much more volatile than domestic revenue (with its volatility increasing recently),

- has remained unpredictable, and

- has not acted as a buffer against GDP shocks.

We hasten to say that this study does not present a counterfactual model of donor behavior in the absence of these initiatives; it could well be that without them aid would be have been even more volatile and less predictable. However, we have not been able to identify an $a$ priori factor, or set of factors, that could have produced this result.

\section{A. Aid Volatility and Procyclicality}

We find, first, that the volatility of aid is much higher than that of revenue and, second, that the relative volatility of aid increased in the early 2000s as compared to the late $1990 \mathrm{~s}$ (Table 1). These results are statistically significant and invariant to alternative definitions of aid and de-trending methods. ${ }^{6}$ Given that we are interested in the relative volatility of aid and

\footnotetext{
${ }^{6}$ Following suggestions by Crowards and Adam (2005), we tested the robustness of our results to changes in aid definitions (gross versus net) and the de-trending methodology. We first reset the parameter $\lambda$ in the Hodrick-Prescott method from 7 to 100 . Second, we applied only first differences to the series instead of using a smoothing technique for de-trending. It turns out that all these estimates of $\Phi$ s are quite similar — see Table A2 summarizing $\Phi_{\mathrm{s}}$ for series in percent of GDP. The detailed results for the alternative denominators are available from the authors on request. Also, it has been argued that (i) the Hodrick-Prescott filter may create spurious serial correlation in de-trended data and (ii) end-period observations have
} 
domestic fiscal revenue, a narrow definition of gross aid - ODA loans and grants, excluding food and emergency aid and debt relief — seems appropriate.

Table 1. Aid Is More Volatile than Revenue and Procyclical, 1975-2003 1/

(Relative volatility of aid and revenue $(\Phi)$, correlation coefficient, and aid-to-revenue ratio)

\begin{tabular}{|c|c|c|c|c|}
\hline & Full Sample & $\begin{array}{c}\text { Subsample } 1 \\
(A / R<25 \%)\end{array}$ & $\begin{array}{c}\text { Subsample } 2 \\
(25 \%<A / R<50 \%)\end{array}$ & $\begin{array}{c}\text { Subsample } 3 \\
(A / R>50 \%)\end{array}$ \\
\hline & \multicolumn{4}{|c|}{ Variables expressed in percent of GDP } \\
\hline Average & $14.2 *$ & $21.9 *$ & $6.8 *$ & $4.8 *$ \\
\hline Median & $6.2 *$ & $12.8 *$ & $4.6 *$ & $3.9 *$ \\
\hline \multicolumn{5}{|l|}{ Frequency indicators } \\
\hline Sample size & 76 & 40 & 16 & 20 \\
\hline Number of countries where $\Phi>1$ & 73 & 40 & 15 & 18 \\
\hline Procyclicality of aid & 0.04 & 0.04 & 0.08 & 0.02 \\
\hline Number of countries where corr $>0$ & 38 & 20 & 8 & 10 \\
\hline \multirow[t]{2}{*}{ Aid-to-revenue ratio (in percent) } & 32.8 & 11.3 & 37.5 & 72.2 \\
\hline & \multicolumn{4}{|c|}{ Variables expressed in constant U.S. dollars per capita } \\
\hline Average & $5.4 *$ & $7.9 *$ & $2.6 *$ & $1.8 *$ \\
\hline Median & $2.5 *$ & $3.6 *$ & $2.5 *$ & $1.4 *$ \\
\hline \multicolumn{5}{|l|}{ Frequency indicators } \\
\hline Sample size & 76 & 42 & 21 & 13 \\
\hline Number of countries where $\Phi>1$ & 60 & 34 & 17 & 9 \\
\hline Procyclicality of aid & $0.12 *$ & 0.03 & 0.20 & $0.30 *$ \\
\hline Number of countries where corr $>0$ & 49 & 23 & 15 & 11 \\
\hline \multirow[t]{2}{*}{ Aid-to-revenue ratio (in percent) } & 29.6 & 11.0 & 38.6 & 75.1 \\
\hline & \multicolumn{4}{|c|}{ Variables expressed in percent of PPP GDP } \\
\hline Average & $10.2 *$ & $10.4 *$ & $10.2 *$ & $2.4 \mathrm{na}$ \\
\hline Median & $5.5 *$ & $5.8 *$ & $3.8 *$ & 2.4 na \\
\hline \multicolumn{5}{|l|}{ Frequency indicators } \\
\hline Sample size & 76 & 66 & 9 & 1 \\
\hline Number of countries where $\Phi>1$ & 73 & 63 & 9 & 1 \\
\hline Procyclicality of aid & 0.00 & 0.02 & $-0.23 *$ & $0.54 \mathrm{na}$ \\
\hline Number of countries where corr $>0$ & 36 & 34 & 1 & 1 \\
\hline Aid-to-revenue ratio (in percent) & 12.1 & 8.8 & 32.0 & 50.8 \\
\hline
\end{tabular}

Source: Authors' calculations.

1/ All variables are in natural logs and filtered by the Hodrick-Precott procedure. $\Phi$ is a ratio of variances.

'*' denotes significance at the 5 percent level, 'na' indicates insufficient number of observations. The null hypothesis is $\Phi \leq 1$.

Procyclicality is measured by a Pearson correlation coefficient between detrended aid and revenue; average of

country-specific correlation coefficients. The null hypothesis is $\operatorname{corr}(\mathrm{A} ; \mathrm{R})=0$.

larger mean square errors than observations in the middle of the sample (Cogley and Nason, 1995). We note, however, that series de-trended with first differences filter yield practically identical results as those de-trended with the Hodrick-Prescott and consider these issues as mute. 
The average volatility of aid relative to revenue $(\Phi)$ is about 14 when variables are expressed in percent of GDP and $51 / 2$ when expressed in constant U.S. dollars per capita. Using medians, which are arguably better statistics in the presence of large outliers, the estimates of the relative volatility of aid are 6 in percent of GDP and $2 \frac{1}{2}$ in constant U.S. dollars per capita. Furthermore, the relative volatility of aid is the highest in the subsamples of the least aid-dependent countries, defined as having aid-to-revenue ratios of less than 25 percent.

Instances where aid is less volatile than revenue $(\Phi<1)$ are rare-between one in twenty-five and one in five. We find only three instances in the GDP-based series (Bolivia, Chad, and Comoros) and 16 in U.S. dollar per capita series (Angola, Bolivia, Burkina Faso, Chad, Comoros, Ecuador, Guinea-Bissau, Laos, Lebanon, Lesotho, Mongolia, Nigeria, Papua New Guinea, Sudan, Uganda, and Vietnam). Moreover, the results in these countries seem to be mostly driven by relatively unstable revenue rather than relatively stable aid. While the absolute volatility of their revenue series was typically a multiple of the sample median, the absolute volatility of their aid series was broadly comparable to the sample median.

On average, aid has been delivered in a mildly procyclical fashion - the average of individual-country correlation coefficients between aid and revenue is positive, albeit statistically insignificant. In other words, declines in de-trended aid tend to be associated with declines in de-trended revenue, and vice versa. ${ }^{7}$ Thus, aid is not only unstable; it tends to fall when domestic sources of revenue weaken. The overall economic impact of aid flows is lower when these are volatile and procyclical, as they fail to assist in, or even work against, consumption smoothing. The procyclicality of aid has been linked to conditionality by bilateral donors and IFIs, particularly in the face of imperfect information about a country's policy efforts. Donors, who cannot observe directly a country's adjustment efforts, may take observable weak macroeconomic indicators as a signal of poor performance and withhold future disbursements of aid.

The initiatives of the late 1990s do not seem to have lowered the relative volatility of aid. (We take 1999 as an interim period and exclude it from the averages.) Indeed, aid has become more volatile in the late 1990s and 2000s - the post-PRSP period - than in the mid 1990 s - the pre-PRSP period, see (Table 2). This result is robust across the three different common denominators used in this paper as well as across averages and medians.

In which countries did aid volatility increase during 2000-2003? One would expect that the poorest countries should have benefited from the PRSP-related initiatives the most. In reality, the declines in the relative volatility of aid have been both rare and comparatively small (Haiti or Togo). In contrast, the increases in relative volatility were frequent and large in several sub-Saharan African countries, such as Benin, Lesotho, and Uganda, but also in Western Hemisphere countries, such as Bolivia and El Salvador.

\footnotetext{
${ }^{7}$ This is not a surprising finding. Gupta et al. (2004) found that even food aid - which is not included in the aid definition used in this section - is procyclical on average, although it is countercyclical in countries with the greatest need.
} 
Table 2. During 2000-03 Aid Has Been More Volatile than Ever Before 1/

(Relative volatility of aid and revenue $(\Phi)$ )

\begin{tabular}{|c|c|c|c|}
\hline & Full Period 2/ & 1995-98 & $2000-03$ \\
\hline & \multicolumn{3}{|c|}{ Variables expressed in percent of GDP } \\
\hline Average & $14.2 *$ & $25.9 *$ & $50.0 *$ \\
\hline Median & $6.2 *$ & $6.8 *$ & $9.4 *$ \\
\hline \multicolumn{4}{|l|}{ Frequency indicators } \\
\hline Sample size & 76 & 76 & 76 \\
\hline \multirow[t]{2}{*}{ Number of countries where $\Phi>1$} & 73 & 69 & 72 \\
\hline & \multicolumn{3}{|c|}{ Variables expressed in constant U.S. dollars per capita } \\
\hline Average & $5.4 *$ & $14.7 *$ & $22.4 *$ \\
\hline Median & $2.5 *$ & $3.1 *$ & $4.5 *$ \\
\hline \multicolumn{4}{|l|}{ Frequency indicators } \\
\hline Sample size & 76 & 76 & 76 \\
\hline \multirow[t]{2}{*}{ Number of countries where $\Phi>1$} & 60 & 57 & 63 \\
\hline & \multicolumn{3}{|c|}{ Variables expressed in percent of PPP GDP } \\
\hline Average & $10.2 *$ & $25.3 *$ & $49.2 *$ \\
\hline Median & $5.5 *$ & $6.7 *$ & $8.3 *$ \\
\hline \multicolumn{4}{|l|}{ Frequency indicators } \\
\hline Sample size & 76 & 76 & 76 \\
\hline Number of countries where $\Phi>1$ & 73 & 68 & 71 \\
\hline
\end{tabular}

Source: Authors' calculations.

$1 / \quad ' *$ ' denotes significance at the 5 percent level. The null hypothesis is $\Phi \leq 1$.

2 / For the exact starting year for each individual country see Table A1.

Breaking down our sample into countries that qualified for debt relief under the HIPC initiative and those who did not, we find comparably similar worsening in relative volatility between 1995-1998 and 2000-2003 in both groups (Table 3). The average Фs roughly doubled during the last four-year period in both groups, while median $\Phi$ s increased in HIPC countries and remained broadly unchanged in non-HIPC countries. Based on this evidence, we would find it difficult to argue that the poorest countries benefited from the PRSP initiative in terms of more stable aid flows. 
Table 3. The Patterns of Aid Volatility in HIPC and Non-HIPC Countries Remain Broadly Unchanged, 1995-2003 1/

(Relative volatility of aid and revenue $(\Phi)$ )

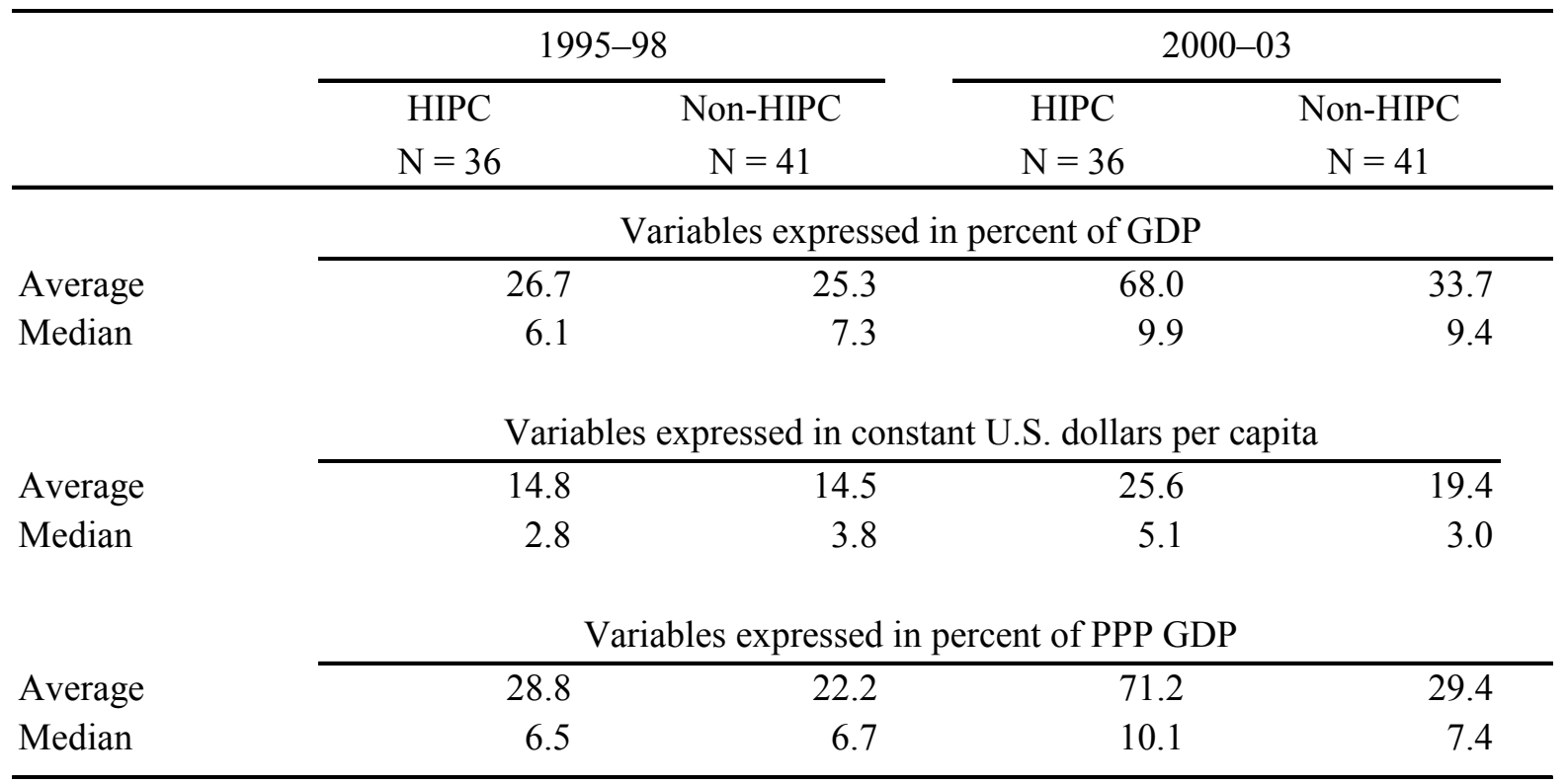

Source: Authors' calculations.

1/ HIPC stands for Heavily Indebted Poor Country.

Figure 3 provides another robustness check of the above results by considering only 50 countries with complete, 1975-2003 series and plotting four-year average and median estimates of $\Phi$ s. Thus, unlike Tables 1 and 2, which are based on unbalanced samples, Figure 3 is based on a balanced sample. We find that the average aid volatility increased in the 2000s after a decline in the late 1990s. The median aid volatility either remained unchanged or increased slightly in the 2000s as compared to the late 1990s. In other words, while aid volatility changed little for the median country, it increased substantially in a few.

Figure 4 backs up our earlier claim that the increases in the average and median $\Phi$ s in recent years are due to more volatile aid. On the one hand, the absolute level of aid volatility ( $\theta^{A}$ ) increased. On the other hand, revenue volatility $\left(\theta^{R}\right)$ either declined or remained broadly stable, depending on the series used. These results are again robust to all transformations used regularly in this paper. 
Figure 3. Selected Countries: Relative Volatility of Aid and Revenue, $\Phi, 1975-2003$ 1/ (Sample average, $\mathrm{N}=50$ )
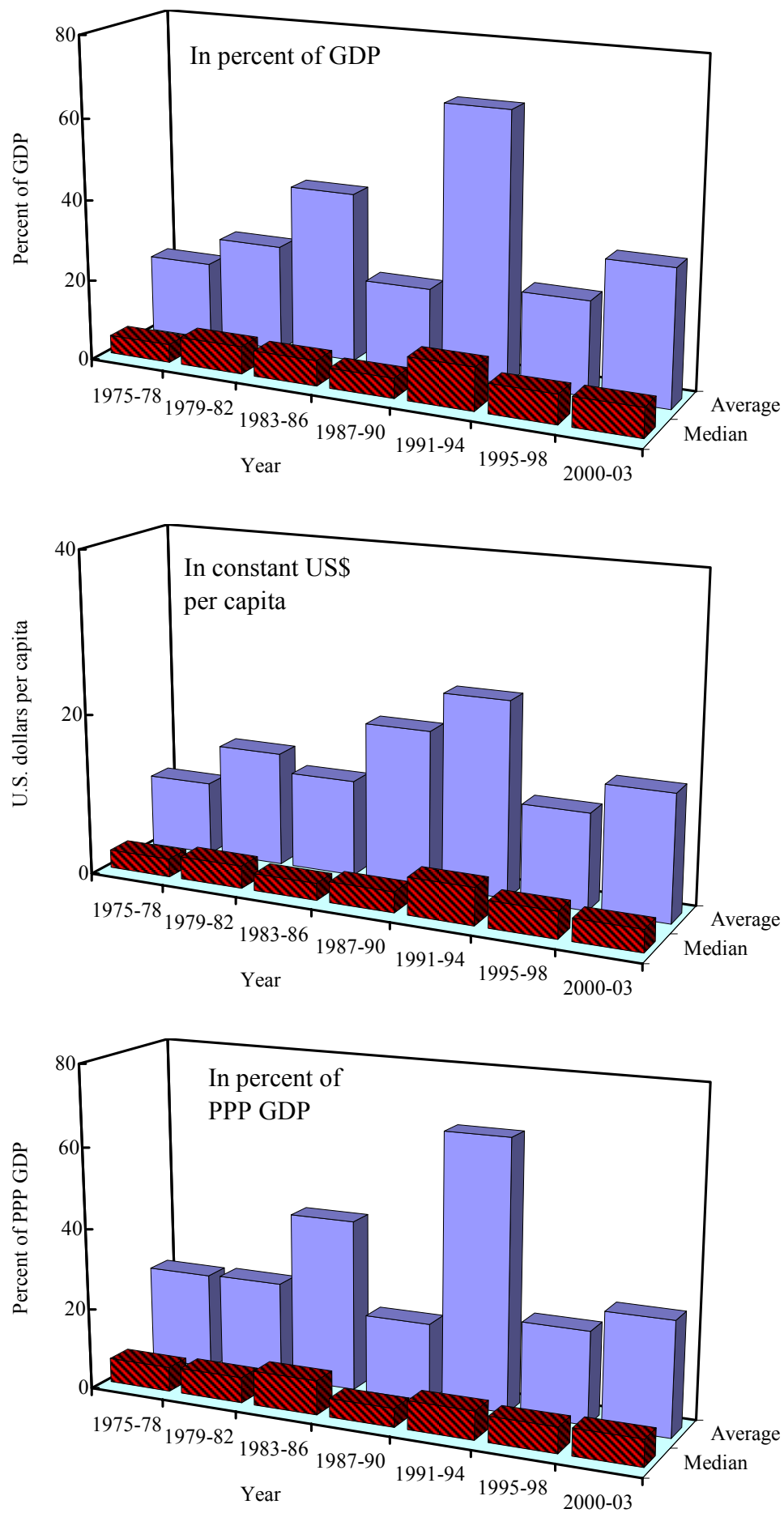

Source: OECD; International Financial Statistics; World Economic Outlook; authors' calculations.

1/ Only countries with complete series (1975-2003) are used in the calculations and the 1999 observation is dropped from the calculations. 
Figure 4. Aid Is Getting More Volatile; Revenue Remains Stable, 1975-2003 1/

(Full sample, $\mathrm{N}=76$ )
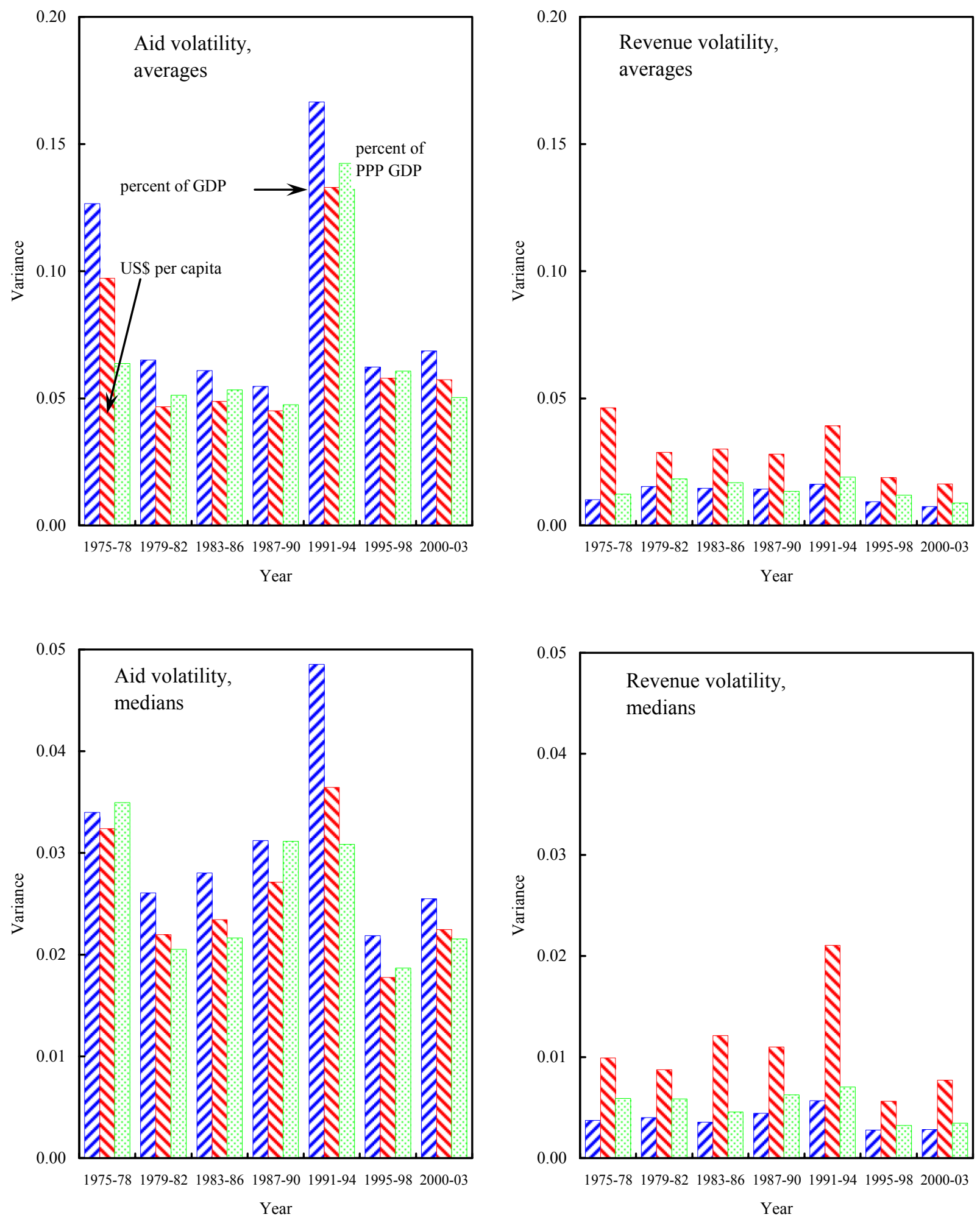

Source: OECD; International Financial Statistics; World Economic Outlook; authors' calculations.

$1 /$ The lines show the sample moments across 76 countries for the selected four-year periods. Volatility is measured by the variance of Hodrick-Prescott filtered series $(\theta)$. 


\section{B. Predictability}

One could argue that aid volatility would be less of a problem if such volatility were predictable. However, fully anticipated aid would be still problematic as most aid-dependent countries face serious liquidity constraints. These countries probably would not be able to borrow in capital markets to completely smooth out a volatile pattern of aid disbursements. Hence, we ask, how reliable are long-term commitments by official lenders?

Unfortunately, no comprehensive database with broadly defined aid commitments and disbursements is compiled. Thus, we rely on commitments and disbursements of long-term loans compiled in the World Bank's Global Development Finance database. It is a reasonable, if imperfect, approximation, because (i) most aid-dependent countries cannot borrow on non-concessional terms and (ii) disbursements in the $G D F$ database are positively correlated with ODA loans for most countries in the OECD database. An admittedly rudimentary assessment of predictability based on contrasting these long-term loan commitments and disbursements yields little evidence that predictability has improved recently. ${ }^{8}$ Indeed, on average, actual loan delivery falls short of promises by more than 40 percent, in particular in the poorest countries.

While the excess of commitments over disbursements declined markedly in the late 1970s and 1980s, this trend disappeared in the 1990s. Indeed, in 2000-03, disbursements fell short of commitments by about one-third (Figure 5, upper panel). In other words, during that period lenders promised, on average, one-half more than they actually disbursed, pushing the commitment-to-disbursement ratio (C-to-D ratio) to its highest level in 20 years. Moreover, we find evidence that the recent increase in the ratio was driven jointly by larger commitments and lower disbursements. During 2000-03 average commitments grew by about 4 percent, relative to 1995-98, while average disbursements fell by some 5 percent during the same period. (As before, we exclude data for 1999 from our calculations.)

Even more disturbing is the finding that this measure of unpredictability has been negatively correlated with the level of development as measured by GDP per capita (using purchasing power parity GDP data; Figure 5, middle panel). An increase in constant PPP GDP by US\$ 100 is associated with a reduction of almost 0.2 in the C-to-D ratio, that is, better reliability of commitments. Countries at the upper end of the income scale appear to have received almost as much loans aid as committed, while countries at the lower end of the income scale have received on average only about one-half of commitments. Comparing the 10th and 90th percentiles of the C-to-D series ordered by GDP per capita, the C-to-D ratios for these two percentiles were 2.0 and 1.0, respectively. The difference in aid predictability remains sizable even if we compare the 25 th and 75 th percentiles.

\footnotetext{
${ }^{8}$ High or erratic (or both), levels of commitments to disbursements may reflect a poor record of policy implementation in aid-recipient countries, and this is not being explicitly controlled for in this case. However, our earlier study (Bulír and Hamann, 2003) showed that shortcomings in aid disbursements relative to commitments cannot be explained entirely in terms of compliance with conditionality under IMF-supported programs. Recently, Celasun and Walliser (2005) found similar results for budgetary aid in eight sub-Saharan countries.
} 
Figure 5. Commitments Are Poor Predictors of Disbursements, 1975-2003 1/ (Commitment-to-disbursement ratio)
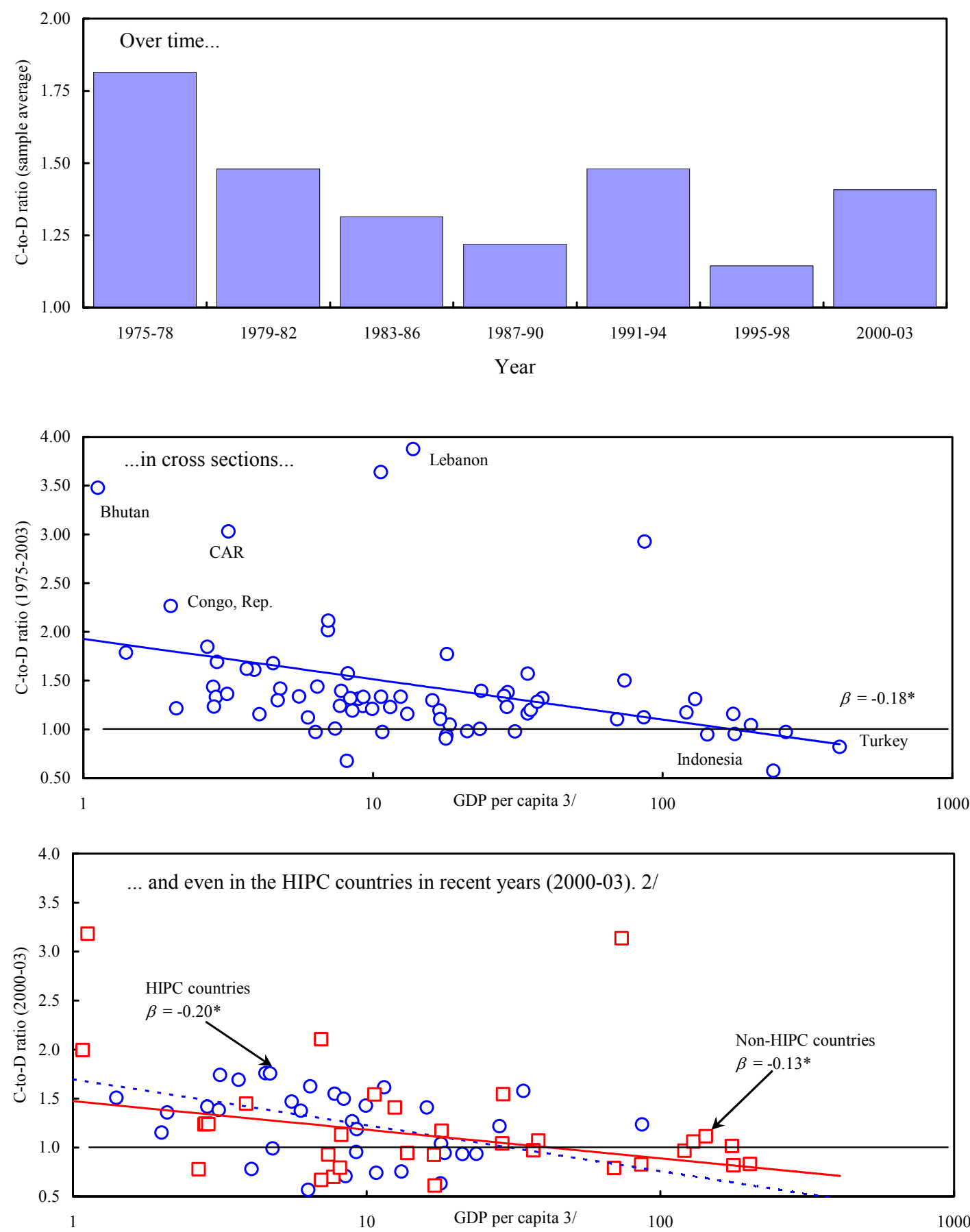

Source: Global Development Finance, World Economic Outlook; authors' calculations.

1/ Long-term loans, excluding IMF lending.

2/ HIPC countries are shown as circles, with a dotted trend line; non-HIPC countries are shown as squares, with a solid trend line. We have excluded the $2001 \mathrm{C}$-to-D observation for the Central African Republic that was changing drastically the slope of the HIPC-country trend line.

3/ In US\$, purchasing parity exchange rate, log scale. All slope coefficients are statistically significant. 
As before, we looked at whether the poorest countries - proxied here by HIPC eligibilitybenefited from the PRSP initiative in terms of lending predictability. We failed to find any statistically significant impact. Breaking down our sample into HIPC and non-HIPC countries and focusing on the 2000-03 period, we find that the negative relationship is similar in both groups of countries (Figure 5, bottom panel). Moreover, the regression slopes are not only comparable to each other in the post-PRSP period (2000-03), but also to the single slope estimated for the full sample period (1975-2003).

The difference in long-term lending predictability between the relatively poorer and relatively richer countries during 2000-03 remains sizable. In non-HIPC countries, which are relatively richer, the median C-to-D ratio was only 1.2 in 2000-03, whereas the median C-to-D ratio in HIPC countries, which are relatively poorer, was 2.0. We interpret these results as suggesting that long-term lending predictability was unaffected by the late 1990's initiatives and that their impact on predictability in the poorest countries was barely noticeable.

\section{Aid and Macroeconomic Shocks: Beyond Procyclicality of Aid}

It could be argued that our aid findings - particularly the procyclicality of aid - are not so serious if donors deliver aid when it is needed the most; that is, during periods of large, negative GDP shocks. ${ }^{9}$ If true, aid would be countercyclical for large negative shocks only and possibly also quite volatile. The advantages of such a scheme are obvious: low-income countries are prone to shocks because their economies are not diversified and are liquidity constrained. In particular, extreme weather fluctuations in many of these countries affect agricultural output, and agriculture employs the bulk of the population. Crises in these countries tend to have permanent output consequences as output fails to recover back to the original trend path (Cerra and Saxena, 2005). It would seem logical that these countries would benefit from a fast and massive income-stabilizing mechanism, even if on average aid has remained unstable.

We fail to find support for the implicit shock-insurance nexus: aid did not compensate for large GDP shortfalls during 1975-2003. We classified the possible outcomes in a matrix, mapping output shocks (increases and decreases in real GDP) and broadly defined aid shocks (increases and decreases in grants, loans, and emergency and food aid in percent of GDP). ${ }^{10}$ Under the income-stabilizing mechanism, donors would step in with additional aid if the country is affected by a negative external shock, such as a natural disaster, drought, or sudden terms-of-trade shock. Intuitively, for this mechanism to work, aid would have to be disbursed fast and in direct proportion to the loss of GDP. We focus on that part of the matrix that contains GDP shortfalls and aid changes.

\footnotetext{
${ }^{9}$ Pallage, Robe, and Bérubé (2005) argue that smoothing out the business cycle in low-income countries could be a major contribution of aid.

${ }^{10}$ Thus, this aid definition is broader than that used in section IV.A. The results for narrowly and broadly defined aid differ, however, very little as the amount of emergency and food aid is small compared to the GDP shocks.
} 
Donors are likely to disburse additional aid only if the income shock was exogenous in nature, as opposed to domestically generated. Aid does not increase during civil war conflicts (e.g., Rwanda or Sierra Leone) or when governments are hostile to donors (e.g., Sudan or Zimbabwe). Thus, rather than using real GDP series, we focused on that part of GDP variability that can be explained by two proxies of external exogenous shocks: terms of trade and agriculture. To this end, we regressed real GDP growth on terms of trade and the share of agricultural output in GDP and used the fitted real GDP growth in our comparisons (see Annex II for further details).

We found that sizable aid increases - by itself more frequent than GDP declines - rarely compensate for output shocks. To test for the presence of an implicit insurance mechanism, we compute the number of instances in which there is a coincidence of a decline in the fitted value of GDP growth and a contemporaneous increase in aid. Additional aid equivalent to the GDP shock almost never arrives when the country is hit by a sizable negative shock of, say, 5 to 10 percent of GDP (Table 4). These results are unaffected by the choice of the output and aid variables - we obtained comparable estimates also for the series with GDP per capita in constant U.S. dollars and narrowly defined aid.

Table 4. Aid Has Been Poor Insurance against Negative GDP Shocks, 1975-2003

(Coincidence of GDP declines and contemporaneous aid increases, in percent)

\begin{tabular}{ccccc}
\hline & \multicolumn{3}{c}{$\begin{array}{c}\text { GDP decline in percent 1/ } \\
\text { (Number of events) }\end{array}$} \\
\cline { 3 - 5 } & & 10 & 5 & $21 / 2$ \\
& & & & \\
\hline $\begin{array}{c}\text { Aid increase 2/ } \\
\text { (Number of events) }\end{array}$ & & & & \\
10 & Coincidence 3/ & 16.7 & 7.1 & 5.1 \\
$(27)$ & & & & \\
5 & Coincidence 3/ & 16.7 & 7.1 & 7.7 \\
$(76)$ & & & & \\
$21 / 2$ & Coincidence 3/ & 33.3 & 21.4 & 17.9 \\
$(174)$ & & & & \\
\hline
\end{tabular}

Source: Authors' calculations.

1/ Real GDP regressed on terms of trade and agricultural output.

$2 /$ Change in aid disbursements, in percentage points of GDP.

3 / Instances in which a given GDP shock (column) coincides with a given increase in aid (row). Expressed as a percent of GDP decline events. Total number of observations $=2,010$. Notes: The interpretation of the first cell in the first row is that out of 6 cases of annual GDP declines of 10 percent or more one of these declines (or 16.7 percent) coincided with an aid increase of 10 percent or more, of which there were 27 in the sample.

In those cases where additional aid was disbursed, it typically fell short of the initial GDP decline (results on the diagonal of the matrix). For example, in our sample of 2,010 annual observations, we have six occurrences of fitted real GDP falling by 10 percent or more. 
Although we have 27 occurrences of aid increasing by 10 percentage points of GDP, these increases coincided with the GDP shock in one case only (Rwanda in 1994), or 16.7 percent. Looking at aid increases of 5 percentage points of GDP, these increases coincided with the 5 percent negative GDP shocks again in only one cases, or 7.1 percent, and so on. These results are fairly similar for off-diagonal combinations of GDP and aid shocks: the probability of receiving compensating aid in the wake of such GDP shocks was between 5 and 30 percent. Very few of those coincidences occurred in the 2000s.

Not only does additional aid fail to arrive at the time of the adverse output shock, but it typically does not arrive at all. We tested the possibility of aid arriving late - that is, the coincidence of a negative GDP shock at time $t$ and a positive aid shock in time $t+1$ - and found that on average the probability of delayed aid was substantially smaller than for contemporaneous aid. Even when we considered jointly contemporaneous and lagged aid, the joint coincidence remained well below one-half for most combinations of negative output shocks and additional aid.

Finally, we find that aid was just as likely to decrease as it was to increase in the wake of a negative GDP shock. For the same distribution of negative GDP shocks as in Table 4, the probability of a cut in aid in the wake of a negative output shock was again between 10 and 20 percent. The detailed results are available from the authors on request.

\section{Conclusions And Policy Implications}

The discussion of aid effectiveness has been gradually moving away from narrowly defined measures of success, such as economic growth or poverty head count, to broader ones that encompass other aspects of the well-being of aid recipients. The issue of the large economic costs associated with macroeconomic volatility in low-income countries and, in particular, the role played by an erratic stream of aid disbursements, is only now starting to be addressed in a systematic manner. Significant work remains to be done in order to understand the real extent of the problem and its key underlying causes.

In this paper, we have reexamined some of the issues taken up in Bulír and Hamann (2003) on the volatility, predictability, and cyclicality of aid. The availability of six new years' worth of data allowed us to look closely at whether the way in which aid is disbursed has improved since the late 1990s, when various initiatives, anchored in PRSPs, were introduced. These initiatives were expected to lead to better compliance with IMF conditionality and a more predictable and less erratic stream of aid flows into low-income countries. Better compliance with conditionality, along with improved donor practices, should have also have led to aid being less procyclical.

The results of our study, however, are not encouraging. The analysis shows that aid has been more volatile than domestic fiscal revenues by a wide margin. We also find little evidence that aid volatility has decreased recently. Aid commitments continue to be poor predictors of disbursements, a problem that is particularly serious among countries with the lowest per capita incomes. The results are equally disappointing for the cyclical behavior of aid. We found disbursements to be procyclical on average and, worse, we found strong evidence that aid has failed to play any meaningful role in assisting countries to cope with large negative 
income shocks. For example, of all countries hit by negative GDP shocks of 5 percent, only one benefited from a concomitant increase in aid. Although the paper does not test directly the impact of the above-mentioned initiatives by donors, IFIs, and aid-recipient countries, the results lead us to conclude that the main underlying causes of aid volatility and unpredictability have not been addressed.

This leaves us to ask: What next? In our view, ongoing work on strengthening the role of donors in helping low-income countries should:

- give macroeconomic stability the prominence it deserves and make it an explicit goal of development assistance; and

- discuss the various mechanisms through which aid can help achieve this goal. The most obvious way in which donors can foster a more stable environment is to disburse aid in a more stable and predictable manner. Donors also need to recognize the benefits of disbursing aid in a countercyclical manner: they should strive to find ways to respond more quickly and more efficiently to large adverse shocks.

But the potential for aid to reduce volatility in low-income countries is not confined to changing the time series properties of aid flows from the donor side. More ambitious targets for reserve accumulation in IMF-supported programs could be formulated, taking into account the extent to which low-income countries are vulnerable to various sources of external volatility, and aid could be used to fund this accumulation. Rules determining the circumstances under which these resources could be used and when they need to be replenished should, of course, also be part of IMF-supported programs. Critical for this to work is, of course, an acknowledgment by donor countries (not just donor agencies) of the tangible and meaningful economic gains associated with the use of aid to help poor countries dampen the destabilizing effects of external shocks.

In closing, we see a strong case for addressing the problems associated with macroeconomic instability in low-income countries in a systematic manner and, in this context, a specific role for aid. Several new initiatives aimed at tackling some of the underlying causes of instability have been introduced recently, including the United Kingdom's proposal for an International Finance Facility (IFF), which led to the launch of the International Finance Facility for Immunization in September 2005; the March 2005 Paris Declaration on Aid Effectiveness; and the IMF's Policy Support Instrument (PSI) and Exogenous Shocks Facility (ESF) introduced in late 2005-see Annex I. In our view, to be effective, these initiatives must form part of a comprehensive approach that (i) addresses in an integrated manner the various sources of economic instability in low-income countries, as opposed to a piecemeal approach in which separate lending facilities or assistance mechanisms are activated by specific events; and (ii) allows the use of bilateral aid flows for stabilization purposes.

What can be done until the donor community comes to terms with the use of aid as an explicit "insurance mechanism?" Aid-dependent countries may want to adopt conservative fiscal policies and these should be supported by the international financial institutions. Building in a cushion of international reserves that could be drawn down to compensate for shortfalls in aid or other sources of budgetary revenue is an essential part of this approach. 


\section{REFERENCES}

Arellano, Cristina, Aleš Bulír, Timothy Lane, and Leslie Lipschitz, 2005, "The Dynamic Implications of Foreign Aid and Its Variability," IMF Working Paper 05/119 (Washington: International Monetary Fund). Available via the internet: http://www.imf.org/external/pubs/ft/wp/2005/wp05119.pdf.

Berg, Andy, and Zia Qureshi, 2005, “The MDGs: Building Momentum," Finance and Development, Volume 42, (September), pp. 21-23. Available via the internet: http://www.imf.org/external/pubs/ft/fandd/2005/09/berg.htm.

Birdsall, Nancy, 2004, "Seven Deadly Sins: Reflections on Donor Failings," CGD Working Paper No. 50 (Washington: Center for Global Development). Available via the internet: http://www.cgdev.org/docs/Working\%20Paper\%2050.pdf

Bulír, Aleš, and A. Javier Hamann, 2003, “Aid Volatility: An Empirical Assessment,” IMF Staff Papers, Vol. 50, No. 1, pp. 64-89. Available via the internet: http://www.imf.org/External/Pubs/FT/staffp/2003/01/bulir.htm

Bulír, Aleš, and Timothy Lane, 2004, "Aid and Fiscal Management," in Helping Countries Develop: The Role of Fiscal Policy, ed. by S. Gupta, B. Clements, and G. Inchauste (Washington: International Monetary Fund).

Cassen, Robert, and Associates, 1986, Does Aid Work? (Oxford: Clarendon Press).

Celasun, O., and J. Walliser, 2005, "Predictability of Budget Aid: Experiences in Eight African Countries," paper presented at the World Bank Practitioners' Forum on Budget Support, May 5-6, 2005, Cape Town. Available via the internet: http://siteresources.worldbank.org/PROJECTS/Resources/409401114615847489/PredictabilityofBudgetAid.pdf

Cerra, Valerie, and Sweta Chaman Saxena, 2005, "Growth Dynamics: The Myth of Economic Recovery,” IMF Working Paper 05/147 (Washington: International Monetary Fund). Available via the internet: http://www.imf.org/external/pubs/ft/wp/2005/wp05147.pdf.

Cogley, Timothy, and James M. Nason, 1995, "Effects of the Hodrick-Prescott Filter on Trend and Difference Stationary Time Series: Implications for Business Cycle Research," Journal of Economic Dynamics and Control, Vol. 19 (January-February), pp. 253-78.

Crowards, Tom, and Christopher Adam, 2005, "Comments on Bulír and Hamann 'Volatility of Development Aid: From the Frying Pan to the Fire'," MAXIMIN, Vol. 2 (London: Department for International Development). 
Fielding, David, and George Mavrotas, 2005, "The Volatility of Aid," WIDER Discussion Paper No. 2005/06 (Helsinki: UNU-WIDER). Available via the internet: http://www.wider.unu.edu/publications/dps/dps2005/dp2005-06.pdf.

Griffin, Keith B., and Enos, J. L., 1970, "Foreign Assistance: Objectives and Consequences," Economic Development and Cultural Change, Vol. 18 (April), pp. 313-27.

Gupta, Sanjeev, Benedict Clements, and Erwin R. Tiongson, 2004, "Foreign Aid and Consumption Smoothing: Evidence from Global Food Aid," Review of Development Economics, Vol. 8, (August), pp. 379-390.

Gupta, Sanjeev, Catherine A. Pattillo, and Smita Wagh, 2006, "Are Donor Countries Giving More or Less Aid?” IMF Working Paper 06/1 (Washington: International Monetary Fund). Available via the internet: http://www.imf.org/external/pubs/ft/wp/2006/wp0601.pdf.

H.M. Treasury, 2005, “G7 Finance Ministers Conclusions on Development” (London), February 5. Available via the internet: http://www.hm-treasury.gov.uk./ otherhmtsites/g7/news/g7 statement conclusions050205.cfm.

International Monetary Fund, 1997, “Experience Under the IMF's Enhanced Structural Adjustment Facility," Finance and Development, Vol. 34 (September), pp. 32-35. Available via the internet: http://www.imf.org/external/pubs/ft/fandd/1997/09/pdf/imf.pdf.

Lensink, Robert, and Oliver Morrisey, 2000, "Aid Instability as a Measure of Uncertainty and the Positive Impact of Aid on Growth," Journal of Development Studies, Vol. 36 (February), pp. 31-49.

Lockhart, Clare, 2005, "From Aid Effectiveness to Development Effectiveness: Strategy and Policy Coherence in Fragile States," paper prepared for the Senior Level Forum on Development Effectiveness in Fragile States, January 13-14, 2005, London. Available via the internet: http://www.oecd.org/dataoecd/33/11/34258843.pdf.

New York Times, 2005, “America’s Promises,” The New York Times, 28 January 2005.

OECD, 2003, "Harmonising Donor Practices for Effective Aid Delivery," DAC Guidelines and Reference Series (Paris: Organisation for Economic Co-operation and Development, Development Assistance Committee). Available via the internet: http://www.oecd.org/dataoecd/0/48/20896122.pdf.

Pallage, Stéphane and Michel A. Robe, 2001, "Foreign Aid and the Business Cycle," Review of International Economics, Vol. 9 (November), pp. 636-67. ,2003, "On the Welfare Cost of Economic Fluctuations in Developing Countries," International Economic Review, Vol. 44 (May), pp. 677-98. 
Pesaran, Hashem M., and Bahram Pesaran, 1997, Working with Microfit 4.0 (Cambridge: Camfit Data Ltd).

Robe, Michel A., Stéphane Pallage, and Catherine Bérubé, 2005, “On the Potential of Foreign Aid as Insurance" (November). Available via the internet: $\underline{\text { http://ssrn.com/abstract }=845549}$

Ramey, Garey, and Valeri A. Ramey, 1995, "Cross-Country Evidence on the Link between Volatility and Growth," The American Economic Review, Vol. 85 (December), pp. $1138-51$.

Tendler, Judith, 1975, Inside Foreign Aid (Baltimore: Johns Hopkins University Press).

Torsvik, Gaute, 2005, “Foreign Economic Aid: Should Donors Cooperate?” Journal of Development Economics, Vol. 77 (August), pp. 503-15.

World Bank, 2000, Small States: Meeting Challenges in the Global Economy, Report of the Commonwealth Secretariat/World Bank Joint Task Force on Small States (Washington: World Bank). Available via the internet: http://wbln0018.worldbank.org/html/smallstates.nsf/(attachmentweb)/final/\$FILE/fin al.pdf. 


\section{A Selective Glossary of Aid-Related Initiatives}

Classifying and ranking in importance the various aid-related initiatives introduced in the 1990s and 2000s is necessarily arbitrary because many were introduced in a piecemeal and gradual manner. Moreover, the IFIs have reviewed their facilities periodically and revised them accordingly. Nevertheless, we believe that 1999 stands out as a natural breaking point owing to the introduction of the Poverty Reduction Strategies. The commonly used acronym PRSP stands for Poverty Reduction Strategy Paper. PRSPs were expected to be the cornerstone of many initiatives introduced simultaneously (or shortly thereafter) and aimed at addressing key issues such as insufficient donor coordination or a lack of ownership by aid recipient countries.

From the mid-1980s, the World Bank and IMF coordinated bilateral and multilateral external assistance to low-income member countries in the context of the Structural Adjustment Facility (SAF) and the Enhanced Structural Adjustment Facility (ESAF). ${ }^{11}$ One of the stated goals of the ESAF was "to bring some order to external cash flow positions, through a combination of debt relief or rescheduling and new resource flows" (International Monetary Fund, 1997).

The ESAF was replaced by the Poverty Reduction and Growth Facility (PRGF) in November 1999. ${ }^{12}$ PRGF-supported programs are framed around comprehensive, country-owned PRSPs. ${ }^{13}$ PRSPs - prepared by governments with the active participation of civil society and other development partners - are then considered by the Executive Boards of the IMF and World Bank as the basis for concessional lending from each institution and debt relief under the joint Heavily Indebted Poor Countries (HIPC) Initiative. ${ }^{14}$ One of the stated goals of PRSP was to "work with other donors for better-coordinated assistance that will enhance aid effectiveness." The "seal of approval" of PRSP/PRGF documents has been used as a monitoring device by bilateral donors.

In 2004-05 a number of initiatives and facilities were introduced with a view of supporting the uneven progress toward the Millennium Development Goals (Berg and Qureshi, 2005) and macroeconomic stability in low-income countries:

${ }^{11}$ See, for example, http://www.imf.org/external/np/exr/facts/esaf.htm.

${ }^{12}$ See, for example, http://www.imf.org/external/np/exr/facts/prgf.htm.

${ }^{13}$ See, for example, http://www.imf.org/external/np/exr/facts/prsp.htm. The PRSP approach is continually being refined - the last report on progress in implementation was completed in September 2004.

${ }^{14}$ See, for example, http://www.imf.org/external/np/exr/facts/hipc.htm. While the HIPC initiative was originally introduced in 1996, its modified version was linked in 1999 to the PRSP initiative. 
- The United Kingdom's International Finance Facility (IFF) to frontload aid to help meet the MDGs; ${ }^{15}$

- Paris Declaration on Aid Effectiveness that agreed to harmonize and align aid delivery; ${ }^{16}$

- The IMF's Policy Support Instrument (PSI) to deliver clear signals on the strength of aid recipients' policies; ${ }^{17}$

- The IMF's Exogenous Shocks Facility (ESF) to provide policy support and financial assistance to low-income countries facing exogenous shocks. ${ }^{18}$

${ }^{15}$ See, for example, $h$ ttp://www.hmtreasury.gov.uk/documents/international_issues/int_gnd_intfinance.cfm.

${ }^{16}$ See, for example, http://www1.worldbank.org/harmonization/Paris/FINALPARISDECLARATION.pdf.

${ }^{17}$ See, for example, http://www.imf.org/external/np/exr/facts/psi.htm.

${ }^{18}$ See, for example, http://www.imf.org/external/np/exr/facts/esf.htm. 


\section{Data Sources and Transformations}

Our database covers 76 countries from 1975 to 2003. The data on gross aid disbursements were taken from the publicly available OECD's Development Assistance Committee (DAC) database (http://www1.oecd.org). The following series were used: ODA grants, total 201; ODA loans extended, 204; Emergency aid, 216; Development food aid, 213; and Offsetting entries for debt relief, 215. Our narrow definition, used in section IV.A includes ODA grants, total 201 and ODA loans extended, 205, while excluding items 213, 215, and 216. Our broad definition includes these items. We tested robustness of our results also with net aid available from the subscription-based World Bank's World Development Indicators (WDI), code DTODAALLDP_1. Commitments and disbursements of long-term loans (excluding IMF disbursement) were drawn from the World Bank's Global Development Finance database $(G D F)$, code DTCOMDPPGCD and DTDISDLXFCD, respectively. Fiscal data used in the paper - total domestic revenue in local currency - are drawn from the IMF's International Financial Statistics (IFS) and the IMF's regional databases, such as the WETA database for Sub-Saharan Africa. All other series - nominal GDP in local currency and in purchasing power parity terms (PPP), market and PPP-based exchange rates vis-à-vis the U.S. dollar, and population - are drawn from the IMF's World Economic Outlook (WEO).

We were able to compile 29 annual observations for 50 countries and 24 annual observations for 18 countries in sub-Saharan Africa, where the revenue series do not begin until 1980 (Table A1). The remaining 8 countries are former communist states that started receiving aid only in the early 1990s and whose series are available for the last 9 to 12 years. Thus, we have a 50-country balanced sample and an unbalanced sample for 76 countries.

We applied the following filters to the universe of aid recipients:

1. Countries were aid recipients during the period under consideration (the minimum number of annual observation is 9 for Tajikistan).

2. To address the small-country bias, only countries with an average population of more than 500,000 were included, eliminating most small island countries (World Bank, 2000).

3 . To focus the analysis on countries where aid has some minimal macroeconomic impact, we included only countries where the sample aid-to-GDP ratio exceeds 1 percent. Thus, we excluded countries that receive either little aid or receive it only sporadically, such as emerging markets that experienced capital account crises.

4. To concentrate on development aid, we limited our sample to countries with average U.S. dollar GDP per capita incomes below 3,000, which eliminated such countries as Argentina and Brazil.

We transformed the series in the following manner:

1. We downloaded the raw data (aid in U.S. dollars and revenue in domestic currency) and expressed both series in common denominators (percentages of nominal GDP, percentages of PPP GDP, and constant per capita U.S. dollars). 
2. We took the natural logarithm in order to have both aid and revenue on the same scale. ${ }^{19}$ 3. Aid and revenue series were found to be nonstationary, or, in a few cases, stationary around a deterministic trend. Thus, we de-trended the series using the Hodrick-Prescott filter (HP), setting the smoothing coefficient $\lambda$ at 7 as suggested by Pesaran and Pesaran (1997).

4. We calculated the sample variances of the aid and revenue series, $\theta^{A}$ and $\theta^{R}$, respectively.

5. A measure of relative volatility was defined as the average of the ratio of these variances, $\Phi=\theta^{A} / \theta^{R}$.

6 . Relative aid variability was assessed by calculating (i) $\Phi$ for each country and (ii) testing the significance of sample averages and medians across countries. Given that $\Phi$ is a ratio of variances - estimated with a common number of observations per country in both the numerator and denominator-we checked the statistical significance of sample averages using an $F$-test.

7. Aid procyclicality was assessed by the correlation coefficient of de-trended aid and revenue.

In the section titled "Aid and macroeconomic shocks: beyond procyclicality of aid" we focused on that part of GDP variability that can be explained by two proxies of external exogenous shocks: terms of trade and the share of agriculture in GDP. To this end, we estimated ordinary least squares (OLS) regressions for each country in our sample,

$\dot{y}_{t}=\alpha+\beta T o T_{t}+\gamma A_{t}+\varepsilon_{t}$,

where $\dot{y}$ is the rate of growth of real GDP, ToT is the index of terms of trade, $A$ is the agricultural output to GDP ratio, and $\varepsilon$ is an error term. The fitted values of GDP growth, $\hat{\dot{y}}$, were then used in Table 4 in lieu of actual GDP growth.

${ }^{19}$ In Bulír and Hamann (2003) we did not take logs, being focused primarily on the absolute size of aid and revenue shocks as relevant for the macroeconomic impact. As far as pure volatility is concerned, variables in logs are preferable because logs eliminate the scale problem. The scale difference remains a problem even after converting all variables into common denominators. For example, the aid-to-revenue ratio is about 0.3 . Thus, all else being equal, the variances of domestic revenue would tend to be about ten times larger than those of aid. 
Table A1. List of Countries and Sample Periods 1/

\begin{tabular}{|c|c|c|c|}
\hline Country & Years & Country & Years \\
\hline Albania & $1992-2003$ & Kyrgyz Republic & $1993-2003$ \\
\hline Algeria & $1975-2003$ & Lao People's Dem. Rep & $1975-2003$ \\
\hline Angola & $1981-2003$ & Lebanon & $1975-2003$ \\
\hline Armenia & $1994-2003$ & Lesotho & $1975-2003$ \\
\hline Bangladesh & $1975-2003$ & Madagascar & $1978-2003$ \\
\hline Benin & $1975-2003$ & Malawi & $1975-2003$ \\
\hline Bhutan & $1981-2003$ & Mali & $1975-2003$ \\
\hline Bolivia & $1975-2003$ & Mauritania & $1975-2003$ \\
\hline Burkina Faso & $1975-2003$ & Mongolia & $1975-2003$ \\
\hline Burundi & $1980-2003$ & Morocco & $1992-2003$ \\
\hline Cambodia & $1987-2003$ & Mozambique & $1975-2003$ \\
\hline Cameroon & $1980-2003$ & Nepal & $1980-2003$ \\
\hline Central African Rep. & $1980-2003$ & Nicaragua & $1975-2003$ \\
\hline Chad & $1980-2003$ & Niger & $1975-2003$ \\
\hline Colombia & $1975-2003$ & Nigeria & $1980-2003$ \\
\hline Comoros & $1980-2003$ & Pakistan & $1975-2003$ \\
\hline Congo, Dem. Rep. of & $1980-2003$ & Papua New Guinea & $1975-2003$ \\
\hline Congo, Republic of & $1980-2003$ & Paraguay & $1975-2003$ \\
\hline Côte d'Ivoire & $1980-2003$ & Peru & $1975-2003$ \\
\hline Djibouti & $1980-2003$ & Philippines & $1975-2003$ \\
\hline Dominican Republic & $1975-2003$ & Rwanda & $1975-2003$ \\
\hline Ecuador & $1975-2003$ & Senegal & $1975-2003$ \\
\hline Egypt & $1975-2003$ & Sierra Leone & $1975-2003$ \\
\hline El Salvador & $1975-2003$ & Sri Lanka & $1975-2003$ \\
\hline Ethiopia & $1980-2003$ & Sudan & $1975-2003$ \\
\hline Fiji & $1975-2003$ & Swaziland & $1975-2003$ \\
\hline Gambia, The & $1975-2003$ & Syrian Arab Republic & $1975-2003$ \\
\hline Ghana & $1975-2003$ & Tajikistan & $1992-2003$ \\
\hline Guatemala & $1975-2003$ & Tanzania & $1975-2003$ \\
\hline Guinea & $1980-2003$ & Thailand & $1975-2003$ \\
\hline Guinea-Bissau & $1980-2003$ & Togo & $1975-2003$ \\
\hline Guyana & $1975-2003$ & Tunisia & $1975-2003$ \\
\hline Haiti & $1975-2003$ & Turkey & $1975-2003$ \\
\hline Honduras & $1975-2003$ & Uganda & $1975-2003$ \\
\hline Indonesia & $1975-2003$ & Vietnam & $1981-2003$ \\
\hline Jamaica & $1975-2003$ & Yemen, Republic of & $1975-2003$ \\
\hline Jordan & $1975-2003$ & Zambia & $1975-2003$ \\
\hline Kenya & $1975-2003$ & Zimbabwe & $1978-2003$ \\
\hline
\end{tabular}

1/ Countries in italics are eligible for debt relief under the HIPC Initiative. 
Table A2. Aid Is Volatile: Nevermind the Definitions and Smoothing Techniques (Relative volatility of aid and revenue $(\Phi)$, in percent of GDP)

\begin{tabular}{|c|c|c|}
\hline & All countries & $\begin{array}{l}\text { Countries with aid } \\
\text { equivalent to at least } 50 \\
\text { percent of revenue }\end{array}$ \\
\hline \multicolumn{3}{|l|}{ I. Aid definitions (Hodrick-Prescott filter, $\lambda=7$ ) } \\
\hline A. Gross aid, narrow definition (loans and grants) $1 /$ & 12.1 & 5.3 \\
\hline B. Gross aid, broad definition (loans, grants, emegency and food aid) & 12.2 & 6.2 \\
\hline C. Net aid, WDI defintion & 13.5 & 7.7 \\
\hline \multicolumn{3}{|l|}{ II. Smoothing techniques (Gross aid; loans and grants) } \\
\hline A. Hodrick-Prescott filter, $\lambda=71 /$ & 12.1 & 5.3 \\
\hline B. Hodrick-Prescott filter, $\lambda=100$ & 11.5 & 5.5 \\
\hline C. First difference & 11.2 & 6.3 \\
\hline
\end{tabular}

Source: Authors' calculations.

1/ Results for gross aid and $\lambda=7$ correspond to Table 1 . 